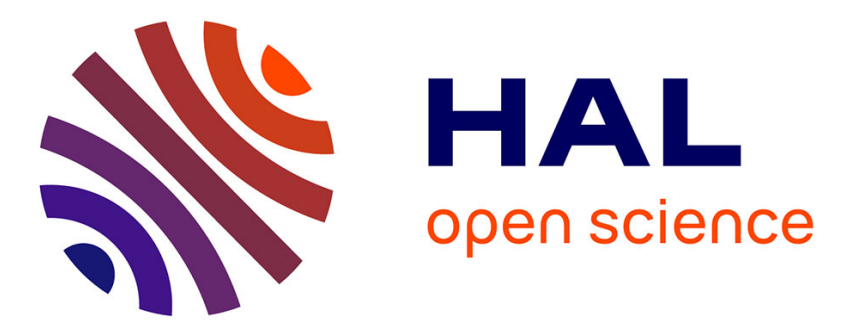

\title{
Ocean acidification reshapes the otolith-body allometry of growth in juvenile seabream
}

Elodie Réveillac, Thomas Lacoue-Labarthe, François Oberhänsli, Jean-Louis

Teyssié, Ross Jeffree, Jean-Pierre Gattuso, Sophie Martin

\section{- To cite this version:}

Elodie Réveillac, Thomas Lacoue-Labarthe, François Oberhänsli, Jean-Louis Teyssié, Ross Jeffree, et al.. Ocean acidification reshapes the otolith-body allometry of growth in juvenile seabream. Journal of Experimental Marine Biology and Ecology, 2015, 463, pp.87-94. 10.1016/j.jembe.2014.11.007 . hal-01084405

\section{HAL Id: hal-01084405 \\ https://hal.science/hal-01084405}

Submitted on 19 Nov 2014

HAL is a multi-disciplinary open access archive for the deposit and dissemination of scientific research documents, whether they are published or not. The documents may come from teaching and research institutions in France or abroad, or from public or private research centers.
L'archive ouverte pluridisciplinaire HAL, est destinée au dépôt et à la diffusion de documents scientifiques de niveau recherche, publiés ou non, émanant des établissements d'enseignement et de recherche français ou étrangers, des laboratoires publics ou privés. 
1 Ocean acidification reshapes the otolith-body allometry of growth in juvenile seabream

3 Elodie REVEILLAC ${ }^{\text {a,b,* }}$, Thomas LACOUE-LABARTHE ${ }^{\text {b,c }}$, François OBERHÄNSLI ${ }^{c}$, Jean-

4 Louis TEYSSIE $^{\text {c }}$, Ross JEFFREE ${ }^{\text {c,d }}$, Jean-Pierre GATTUSO ${ }^{\text {e,f }}$, Sophie MARTIN ${ }^{\text {c,g,h }}$

6 a. Agrocampus Ouest, UMR985 ESE Ecologie et Santé des Ecosystèmes, 65 rue de Saint-Brieuc, CS 84215, 35042 Rennes cedex, France.

8 b. Littoral Environnement et Sociétés, UMR 7266 CNRS - Université de La Rochelle, 2 rue

c. IAEA Monaco, Radioecology Laboratories, 4 Quai Antoine $1^{\text {er }}$, MC-98000 Principauté de Monaco, Monaco

d. School of the Environment, C3, Faculty of Science, University of Technology, Sydney, PO Box 123, Broadway, NSW 2007, Australia

e. CNRS-INSU, Laboratoire d'Océanographie de Villefranche, B.P. 28, 06234 Villefranche-surmer Cedex, France

16 f. Sorbonne Universités, UPMC Univ. Paris 6, Observatoire Océanologique, 06234 Villefranche-

g. CNRS, UMR 7144, Station Biologique de Roscoff, Place Georges Teissier, 29688 Roscoff Cedex, France

h. Sorbonne Universités, UPMC Univ. Paris 6, Laboratoire Adaptation et Diversité en Milieu Marin, Station Biologique de Roscoff, Place Georges Teissier, 29688 Roscoff Cedex, France

\footnotetext{
* Correspondence to: E. Réveillac, Agrocampus Ouest, Ecologie Halieutique, 65 rue de Saint-Brieuc, CS 84215, 35042 Rennes cedex, France. Tel +33 223485538, E-mail elodie.reveillac@ gmail.com
} 


\section{ABSTRACT}

The effects of elevated $\mathrm{CO}_{2}$ partial pressure $\left(p \mathrm{CO}_{2}\right)$ on otolith calcification and on the coupling between the somatic and otolith growth were investigated in juvenile gilthead seabream Sparus aurata. Six-month old individuals were raised during seven weeks under four $p \mathrm{CO}_{2}$ conditions set according to projected future ocean acidification scenarios. Body and otolith biometric parameters were measured throughout the experiment along with the otolith biomineralization monitored using a radiotracer technique based on ${ }^{45} \mathrm{Ca}$ incorporation. Seabream exhibited somatic growth resilience to all treatments. In contrast, increased growth rate and shape complexity of otoliths were observed with a $\mathrm{pH}_{\mathrm{T}}$ drop from 8.1 to 7.5. Hypercalcification was observed under lowered $\mathrm{pH}$, with a rate of calcium incorporation increasing by up to $18 \%$ between $\mathrm{pH}_{\mathrm{T}} 8.1$ and $\mathrm{pH}_{\mathrm{T}}$ 7.7. This work highlighted an uncoupling of otolith and body growth of juvenile seabream within $40 \mathrm{~d}$ at $\mathrm{pH}_{\mathrm{T}} 7.9$ projected to be reached by the end of the century. As the otolith is an essential tool used in reconstructing fish life history, this work suggests that information resulting from otolith studies should be interpreted with caution with respect to the potential impacts that ocean acidification projected modifications could have on otolith biomineralization.

Keywords: climate change; ocean acidification; otolith calcification; somatic-otolith growth allometry; temperate coastal fish

\section{INTRODUCTION}

On $9^{\text {th }}$ May 2013, the concentration of carbon dioxide $\left(\mathrm{CO}_{2}\right)$ in the atmosphere reached the symbolic threshold of 400 ppm in Mauna Loa, Hawaii (IPCC, 2013), a level never reached at this reference site. The increase of atmospheric $\mathrm{CO}_{2}$ from a preindustrial value of $280 \mu \mathrm{atm}$ is the result of fossil fuel combustion, cement production and land use change (Ciais et al., 2013). 
51 IPCC projections suggest further increase in the coming decades with concentrations reaching

$52490 \mathrm{ppm}$ in 2050 and more than $1370 \mathrm{ppm}$ by 2100 (IPCC, 2013). The ocean is a major carbon

53 sink, absorbing about $25 \%$ of anthropogenic $\mathrm{CO}_{2}$ emissions thus limiting the greenhouse gas

54 effects on climate (Le Quéré et al., 2013). The increase in $p \mathrm{CO}_{2}$ in the ocean has already led to a

$55 \mathrm{pH}$ decline of 0.1 unit since the industrial revolution and to major shifts in the ocean carbonate

56 chemistry, i.e. increased concentrations of dissolved inorganic carbon and bicarbonate ions,

57 decreased carbonate concentration, altogether leading to 'ocean acidification' (Caldeira and

58 Wickett, 2005). The $\mathrm{pH}$ of the surface ocean is expected to decline by 0.06 to 0.32 units by the

59 end of century (Ciais et al., 2013), resulting in an unprecedented change of seawater chemistry

60 equilibrium since the last 800,000 years (Zeebe and Ridgwell, 2012).

61 For a decade, a growing body of experimental studies has examined the response of marine 62 organisms to decreased $\mathrm{pH}$ across multiple taxa. Impacts on early life stages have been of 63 particular concern in fish (Baumann et al., 2012) because it has been hypothesized that animal 64 embryos and larvae may not be as resilient to physiological stress as juveniles and adults 65 (Pörtner, 2008), and because recruitment cohorts lay the foundation for population success and 66 connectivity (Planes et al., 2009). Nevertheless juveniles of coastal fish may be more exposed to 67 high $\mathrm{CO}_{2}$ levels than earlier life stages and deserves particular attention. Indeed, unlike in the open ocean, seawater $p \mathrm{CO}_{2}$ is known to vary considerably in coastal waters depending on land-

69 driven eutrophication, which adds to the uptake of atmospheric $\mathrm{CO}_{2}$, locally amplifying ocean 70 acidification (Cai et al., 2011; Guinotte and Fabry, 2008). Juvenile fish settling in coastal areas 71 during their high metabolic and fast growing phase could be severely challenged by hypercapnic 72 conditions.

73 Based on the sparse current knowledge, adult physiological performance allows fish to cope with 74 extracellular acidosis caused by increasing $\mathrm{pCO}_{2}$ (e.g. Melzner et al., 2009b). But in early-life 75 stages of multiple taxa including fish, increasing $p \mathrm{CO}_{2}$ was shown to affect calcification of shells 
and skeletons due to a drop in the carbonate availability (e.g. Gattuso et al., 1998; Riebesell et al., 2000). Munday et al. (2011a) observed no effects on spiny damselfish otolith calcification at $850 \mu \mathrm{atm}$, while Munday et al. (2011b) and Checkley et al. (2009) highlighted an otolith hypercalcification in white sea bass larvae exposed at 993 and $2558 \mu \mathrm{atm} p \mathrm{CO}_{2}$ and in clownfish larvae at $1721 \mu \mathrm{atm} p \mathrm{CO}_{2}$, respectively. In cases of calcification modulation, otolith morphology can be affected, which may have negative repercussions on the behaviour and acoustic function in fish, decreasing their survival probabilities (Bignami et al., 2013a; Popper et al., 2005). It has also been recently reported that otolith increment growth can be uncoupled from somatic growth in fish larva raised under high $p \mathrm{CO}_{2}$ conditions, then having potential implications for the study of fish populations (Bignami et al. 2013b). Understanding the way ocean acidification can affect the process of otolith formation is decidedly important in many perspectives among which is seems crucial to delineate how the environment can affect its growth and influence its coupling with the structural skeleton growth. If otoliths indeed ensure the fish's biological hearing and balance functions, they are also an essential tool used in fisheries biology to reconstruct individual life history in terms of age and somatic growth relationship (age-length keys) and attended habitats (Campana and Neilson, 1985; Campana, 2005).

This paper aims at evaluating the impacts of ocean acidification on the calcification rate of fish otoliths and on the understudied coupling between otolith and somatic growth in juveniles. These questions were investigated experimentally using a nuclear tracking approach, following the ${ }^{45} \mathrm{Ca}$ incorporation in otolith for 7 weeks of exposure to 4 realistic $p \mathrm{CO}_{2}$ levels projected for the nearfuture. The gilthead seabream Sparus aurata was chosen due to its ecology and high economic value. Temperate and widely distributed over the North-Eastern Atlantic Ocean and the Mediterranean Sea, this coastal species is subjected to recreational and professional fishing and is increasingly aquacultured (FAO, 2014). In the Mediterranean Sea, it is the first marine fish species cultured with more than 140,000 tonnes produced in 2010 in 17 countries for a worth $c a$. 
US\$ 785 million (GFCM, 2013).

102

103

\section{MATERIALS AND METHODS}

2.1 Organisms, radiotracer and experimental procedures

105 Six-month old juveniles of seabream Sparus aurata have been purchased at the "Cannes 106 Aquaculture" fish farm of Monaco and were placed for three weeks in an open-circuit 5001 tank 107 in the IAEA-EL premises for acclimation.

108 Then, 200 fish juveniles of $c a .50 \mathrm{~mm}$ were randomly assigned in four 201 circular tanks (one 109 tank per treatment) filled with filtered $(0.45 \mu \mathrm{m})$ and UV-sterilized Mediterranean seawater (38 110 p.s.u.) pumped from $30 \mathrm{~m}$ depth in the Bay of Monaco. In each experimental tank (closed 111 system), seawater was constantly aerated. The light/dark cycle was $12 \mathrm{~h} / 12 \mathrm{~h}$. Fish were fed daily 112 ad libitum with pellets. After feeding, not ingested food has been removed and $80 \%$ of the 113 volume was renewed daily with sterilized and filtered seawater. Temperature was maintained at $11421^{\circ} \mathrm{C}$ and controlled in each bath to within $\pm 0.5^{\circ} \mathrm{C}$ using temperature controllers connected to $115300 \mathrm{~W}$ submersible heaters. Seawater $\mathrm{pH}\left(\mathrm{pH}_{\mathrm{T}}\right.$ on the total scale, Dickson et al., 2007) was 116 adjusted to the desired level from ambient $\mathrm{pH}_{\mathrm{T}}$ of 8.1 (corresponding to $475 \mu \mathrm{atm}$ of $p \mathrm{CO}_{2}$ ) to 117 low $\mathrm{pH}_{\mathrm{T}}$ of 7.9, 7.7, and 7.5 (700, 1200 and $2000 \mu \mathrm{atm}$, respectively), as derived from various 118 models on trajectories of carbon emissions to the near-future (IPCC, 2013). The pH was 119 controlled in each bottle to within $\pm 0.05 \mathrm{pH}$ unit using a pH-stat system (IKS, Karlsbad). The 120 experimental containers were continuously bubbled with $\mathrm{CO}_{2}$-free air and discrete amounts of 121 pure $\mathrm{CO}_{2}$ were added by the $\mathrm{pH}$-stat system. $\mathrm{pH}$ and alkalinity were measured and set according 122 to Martin et al. (2011) using the R package seacarb (Proye and Gattuso, 2003).

123 Seawater in each bottle was spiked with ${ }^{45} \mathrm{Ca}\left(10 \mathrm{kBq} \mathrm{l}^{-1}\right)$. Radiotracers were purchased from 124 Radioisotope Centre Polatum, Poland, ${ }^{45} \mathrm{Ca}$ [as $\left.{ }^{45} \mathrm{CaCl}_{2} ; \mathrm{T}_{1 / 2}=163 \mathrm{~d}\right]$. Stock solutions were 125 prepared in $\mathrm{H}_{2} \mathrm{O}$ to obtain radioactivities that allowed the use of spikes of only a few microliters 
126 (typically 5-10 $\mu$ ). The radiotracer spikes were renewed at each water change and were checked 127 (i.e. counted in $1 \mathrm{ml}$ of seawater) before and after each water renewal in order to maintain 128 radiotracer concentrations.

129 Fish were maintained for $40 \mathrm{~d}$ at the four $\mathrm{pH}$ treatments and continuously exposed to dissolved $130{ }^{45} \mathrm{Ca}$ in seawater. Five fishes were collected every 3 or $7 \mathrm{~d}$ in each tank, anesthetized with clove 131 oil prior to decerebration and then measured in length and weight to the nearest $0.1 \mathrm{~mm}$ and 1 $132 \mathrm{mg}$, respectively. Left and right otoliths (sagittae) were extracted and photographed using a 133 Leica DFC420 camera mounted on a stereomicroscope (Leica LZ12). Otolith surface area (OSA, $134 \mathrm{~mm}^{2}$ ), maximum Feret diameter $(\mathrm{OF}, \mathrm{mm})$ and roundness (OR) were calculated using ImageJ 135 software and weight measurement was made to the nearest $0.1 \mathrm{mg} .{ }^{45} \mathrm{Ca}$ content was then 136 determined. Paired radiolabelled sagittal otoliths from the same individual were pooled and 137 dissolved adding $300 \mu \mathrm{L}$ of hydrochloric acid $(\mathrm{HCl}, 37 \%)$ at $80^{\circ} \mathrm{C}$. After evaporation, the 138 residues were dissolved in $1 \mathrm{~mL}$ of distilled water. Biological and seawater samples were 139 counted after adding $10 \mathrm{~mL}$ of scintillation liquid, Ultima GoldTM XR (Perkin Elmer). 140 Emissions were measured with a liquid scintillation analyzer (Tri-Carb, Packarb 1600 TR or 141 Perkin Elmer 2900 TR) calibrated with an appropriate standard for each counting that was used. 142 Counting times were adapted to obtain relative propagated errors less than $5 \%$ (from 10 min to $14324 \mathrm{~h}$ ). Corrections for the physical half-life time and background noise were done in order to 144 determine the ${ }^{45} \mathrm{Ca}$ activities at the sampling time $(\mathrm{Bq})$. The uptake of $\mathrm{Ca}$ in the otolith was then 145 expressed as the amount of $\mathrm{Ca}$ incorporated $\left(\mathrm{Q}_{\mathrm{Ca}}\right.$, in $\mu \mathrm{mol} \mathrm{Ca} \mathrm{g}^{-1}$ of otolith dry $\mathrm{wt}$ ) and following 146 the equation (Martin et al., 2011): $\mathrm{Q}_{\mathrm{Ca}}=\left[\left(\mathrm{A}_{\mathrm{cut}} / \mathrm{A}_{\mathrm{sw}}\right) \times \mathrm{C}_{\mathrm{sw}}\right] \times 10^{3}$

148 where $\mathrm{A}_{\text {cut }}$ is the total ${ }^{45} \mathrm{Ca}$ activity in each otolith (in $\mathrm{Bq}$ ), $\mathrm{A}_{\mathrm{sw}}$ is the time-integrated activity (in $149 \mathrm{~Bq} \mathrm{~g}^{-1}$ ) in seawater during the time of exposure and $\mathrm{C}_{\mathrm{sw}}$ is the total $\mathrm{Ca}$ concentration in 150 Mediterranean seawater $\left(0.0114 \mathrm{mmol} \mathrm{g}^{-1}\right)$. 
153 Due to compromises with experiment cost, radioprotection rules and waste management 154 possibilities with respect to the use of radioisotope ${ }^{45} \mathrm{Ca}$, only one $20-1$ tank has been dedicated to each $\mathrm{pH}$ conditions. Therefore, fish sampled along the experiment course at regular sampling time ( $\mathrm{n}=5$ (and 10) per sampling time (at 40 d) per condition) have been considered as pseudoreplicates (Hurlbert, 1984). Accordingly, the effect of $\mathrm{pH}$ on measured physiological or morphological responses of fish has been tested through multiple linear regression considering the $\mathrm{pH}$ as a continuous covariate (Havenhand et al., 2011). Linear regressions were used to test the effects of $\mathrm{pH}$ (continuous covariate), on relationships between otolith biometrics (i.e. otolith 161 surface area (OSA), weight (OW), maximum diameter (Feret's diameter, OF), roundness (OR)) 162 and fish total length (FTL) or Time, including a FTL (or Time) x pH interactions. When FTL (or 163 Time) x pH interaction was not significant, a simpler model without interaction (i.e. Time (or FTL $)+p H)$ has been computed (Crawley, 2005).

To evaluate the effect of the $\mathrm{pH}$ treatment on the asymmetry of paired-otoliths (regarding leftright differences in OSA, OF and OR), log-transformed data were injected in a Brown-Forsythe robust Levene test of homogeneity of variances based on deviation from the median.

168 The amount of Ca incorporated in otoliths were standardized to the otolith weight and expressed 169 according to the Time of experiment. Ca incorporation data ( $\mathrm{mmol} \mathrm{g}^{-1}$ otolith dry weight) have 170 been fitted by multiple linear regression with Time $\mathrm{x} \mathrm{pH}$ as continuous covariates.

171 Results are expressed as mean \pm s.d. Significance was considered at $p<0.005$. All statistical 172 treatments have been done using R (R Core Team, 2013). 
176 During the experiment, the fish biomass in each tank did not exceed 5 g. $1^{-1}$, i.e. far below the EU

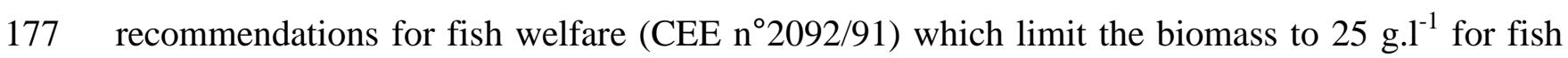

178 aquaculture in marine environment. Along the $40 \mathrm{~d}$ of ${ }^{45} \mathrm{Ca}$ exposure, $\mathrm{pH}_{\mathrm{T}}$ was maintained at a 179 mean $( \pm$ s.d.) of $7.50 \pm 0.06,7.69 \pm 0.03,7.89 \pm 0.05$ and $8.04 \pm 0.05$ (Table 1 ), corresponding to $180 p \mathrm{CO}_{2}$ of $c a .2000,1200,700$, and $475 \mu \mathrm{atm}$, respectively. Mean temperature was $21.0^{\circ} \mathrm{C} \pm 0.7$.

181 Mean $A_{\mathrm{T}}$ of renewed seawater was $2.595 \pm 0.003 \mathrm{mmol} . \mathrm{kg}^{-1}$. It changed by a maximum of 0.2 $182 \mathrm{mmol} \mathrm{kg}{ }^{-1}$ between two seawater renewals. $C_{\mathrm{T}}$ increased from 2410 to $2690 \mu \mathrm{mol} \mathrm{kg}^{-1}$ whereas 183 the $\mathrm{CO}_{3}{ }^{2-}$ concentration decreased from 240 to $80 \mu \mathrm{mol} \mathrm{kg}{ }^{-1}$ with decreasing $\mathrm{pH}$. In all 184 conditions, the saturation state with respect to aragonite was higher than 1.

\subsection{Somatic versus otolith growth}

Fish somatic growth in total length and weight was significant over the 40 days period of the experiment (p-value $<0.001$, Table 2), slightly inflecting from day 30 (Figure 1, A,B). As a mean, fish grew by $0.36 \mathrm{~mm} . \mathrm{d}^{-1}$ and $0.043 \mathrm{~g} . \mathrm{d}^{-1}$, a growth rate close to the $0.0534 \mathrm{~g} . \mathrm{d}^{-1}$ value measured in juveniles seabream $(1.24 \pm 0.02 \mathrm{~g})$ reared in closed system tank at a density of 1.5

191 g. l $^{-1}$ (Kalogeropoulos et al., 1992). Similarly Kim et al. (2012) reported a mean weight growth rate of $0.0364 \mathrm{~g} . \mathrm{d}^{-1}$ for young juveniles of red seabream reared from $1.46 \mathrm{~g}$ for 42 days, arguing for adequate rearing conditions in our experiment allowing a normal growth and development of the juveniles (Figure 2). The $\mathrm{pH}$ treatments had no impact on those body growth parameters and intercepts did not differ between treatments meaning the initial group of juveniles was homogeneous ( $\mathrm{p}$-value $>0.05$ ). In contrast, the allometric relationship between otolith surface area and fish total length (Figure 3.A), though still linear, was altered by the decreasing $\mathrm{pH}$ (pvalue $<0.001$, Table 2) with a lower slope value observed at $\mathrm{pH}_{\mathrm{T}}=8.1$ compared to $\mathrm{pH}_{\mathrm{T}}=7.9$ 199 and 7.7, and even more compared to $\mathrm{pH}_{\mathrm{T}}=7.5$ (Figure 3.A). The otolith's Feret diameter and 200 fish total length relationship tended also to be modified in the two lowest $\mathrm{pH}$ conditions though 
201 not significantly (Figure 3.B, Table 2). The otolith roundness was not related to fish total length 202 except at $\mathrm{pH}_{\mathrm{T}} 7.5$ where the linear relationship was low but significant (Figure 3.C, p-value < 203 0.0046) indicating a faster evolution of the otolith toward a less round shape along with body 204 growth at the lowest $\mathrm{pH}$ than at more elevated ones. Finally, the otolith weight was linearly 205 correlated to the otolith surface area during all the experiment and whatever the $\mathrm{pH}$ treatment 206 (Table 2), indicating that the density of the otolith was not affected by $p \mathrm{CO}_{2}$.

\subsection{Asymmetry}

209 Levels of both surface area and roundness asymmetry between left and right sagittal otoliths 210 (Figure 4) of juvenile seabream were not affected by $\mathrm{pH}$ treatments over the 40 days (Brown211 Forsythe robust Levene Test based on deviation from the median; $p>0.05)$. Disequilibrium of 212 the symmetry in the otolith surface area toward a greater OSA of the right otolith was observed 213 during the first half of the experiment whatever the $\mathrm{pH}$ (Figure 4.A.), but disappeared in animals 214 sampled during the last 10 days of experiment. No asymmetry of the otolith roundness was 215 observed (Figure 4.B.).

\subsection{Calcification}

218 The calcification of otolith was followed through ${ }^{45} \mathrm{Ca}$ accumulation throughout the 40 days of 219 experiment (Figure 5). The incorporation of $\mathrm{Ca}$ in otolith of juvenile seabreams followed a linear 220 equation whatever the $\mathrm{pH}$ (Table 3), which is consistent with the linear growth of fish over the 221 experiment. Based on the slope calculated for each $\mathrm{pH}$, we could estimate that for the fish reared 222 at $\mathrm{pH}_{\mathrm{T}} 8.1$ rates of $\mathrm{Ca}$ incorporation were 13, 17 and $18 \%$ lower than rates performed at $\mathrm{pH}_{\mathrm{T}}$ 7.9, $223 \quad 7.7$ and 7.5 , respectively. 
Assessing whether elevated $p \mathrm{CO}_{2}$ and lowered $\mathrm{pH}$ impact marine fauna and flora and to what extent it can affect individual, population and ecosystem function is a major concern (Fabry et al., 2008; Hilmi et al., 2013; Melzner et al., 2009a). Recent studies have reported that hypercapnia can challenge fish physiology (e.g. Melzner et al., 2009b; Michaelidis et al., 2007), affect the behaviour (Simpson et al., 2011) and growth (Baumann et al., 2012) and impact calcified structures biomineralized from the early-life stages (Checkley et al 2009, Ries et al. 2009). Our study shows that responses can be contrasted at the sub-individual integration level.

\subsection{Effect of elevated $\mathrm{pCO}_{2}$ on the coupling of fish somatic and otolith growth}

Juvenile seabream Sparus aurata reared under $4 p \mathrm{CO}_{2}$ treatments during $40 \mathrm{~d}$ exhibited no variation in somatic growth. As documented, physiological performance of fish could be expected to allow them to cope with elevated $p \mathrm{CO}_{2}$ (Melzner et al., 2009b) without significantly affecting the animal's growth (Hurst et al., 2012; Ishimatsu et al., 2008). Michaelidis et al. (2007) demonstrated that long-term hypercapnia may cause a shift from aerobic to anaerobic metabolism in seabream Sparus aurata, but only at dramatically elevated $p \mathrm{CO}_{2}(\sim 5000 \mu \mathrm{atm})$. This suggests that this species is able to cope with realistic increasing $p \mathrm{CO}_{2}$, according to IPCC scenarios, without extra-energy demand and might thus maintain its juvenile somatic growth rate as observed in this study.

In contrast, a modulation of the otolith biomineralization was observed, with an increase of the calcification rate observed from $700 \mu$ atm after 40 days of exposure. This means that juvenile seabream might be subjected to the hypercalcification of their otoliths by the end of the century with respect to IPCC projected $\mathrm{CO}_{2}$ levels. Only Bignami et al. (2013b) reported such a shortterm effect of increased $p \mathrm{CO}_{2}$ under the threshold of $800 \mu \mathrm{atm}$, and this was at the larval stage of cobia Rachycentron canadum. Here, the higher growth rate of the otolith surface area under 
rising $p \mathrm{CO}_{2}$ was directly linked with the increase of the net calcification rate calculated on the basis of ${ }^{45} \mathrm{Ca}$ incorporation. The linearity of calcium incorporation with time was not disrupted by $p \mathrm{CO}_{2}$ treatments, but it did provide evidence of a critical difference in the mineralisation slopes. The hypermineralization of calcareous structures in organisms maintained in decreasing $\mathrm{pH}$ and in less favourable chemical condition for $\mathrm{CaCO}_{3}$ precipitation (lower carbonate saturation state, $\Omega_{\text {arg }}$ ) has been already observed in species of various taxonomic groups characterized by efficient capacities to maintain blood/hemolymph homeostasis, such as crustaceans (Ries et al., 2009), cephalopods (Dorey et al., 2012; Gutowska et al., 2010) and fishes (Bignami et al., 2013b; Checkley et al., 2009). Indeed, the active uptake of bicarbonate ions in internal medium to compensate blood acidosis is expected to contribute at increasing $\Omega_{\text {arg }}$ in the endolymph fluid surrounding the aragonitic otolith (Borelli et al., 2003). The precipitation of $\mathrm{HCO}_{3}{ }^{-}$with $\mathrm{Ca}^{2+}$ in endolymph leads in turn to active proton extrusion to avoid impeding the calcification process (Allemand et al., 2007). Nonetheless, the cellular mechanisms underlying the hypercalcification of otoliths in this context of ocean acidification remains poorly understood (Munday et al., 2011b) and require further insights.

The observed uncoupling of fish body and otolith growth may have implications in fisheries studies. Indeed, back-calculation of fish size from the otolith size is a common and quite highly effective tool used in fisheries biology (Campana and Neilson, 1985; Mosegaard et al., 1988; Payan et al., 1997). It can be used to determine fish-prey size spectra from otoliths collected in the stomach contents of predators (Blanco et al., 2001; Markaida and Sosa-Nishizaki, 2003; Ross et al., 2005). It is also commonly used to infer fish-size at age, based on otolith growthincrements reading (Secor and Dean, 1989). However to be reliable, body and otolith growth have to be uniquely and confidently linked throughout the developmental stage or time period of interest. A body of studies has shown how complex this relationship can be (reviewed in Wilson et al., 2009), being potentially impacted by environmental parameters fluctuations such as 
temperature (Mosegaard et al., 1988; Takasuka et al., 2008). To date, "growth-effect" and "ageeffect" were the two major explanations of the uncoupling between somatic and otolith growth (Wilson et al., 2009). This work presents the perspective that the distortion of the fish-otolith allometric relationship can also originate from the modulation of the otolith growth induced by variations of environmental parameters to which body growth is (more) resilient. Ocean acidification, as a compound of the global change, appears here to alter this relationship.

\subsection{Effect of increased $\mathrm{pCO}_{2}$ on otolith shape}

Ocean acidification has also been reported to affect other otolith metrics that were monitored during this experiment. As otolith weight increased in the same way as the otolith surface area, no effect of $p \mathrm{CO}_{2}$ increase up to $2000 \mu$ atm was observed on seabream otolith density. These results are consistent with Bignami et al. (2013b) who did not observe any density modification of the otolith in cobia larvae until $800 \mu \mathrm{atm}$. Nevertheless, they reported an increase of $6 \%$ density when they experimentally increased conditions to $2100 \mu \mathrm{atm}$, suggesting an alteration of the otolith's mass-size relationship under extreme hypercapnia conditions. Seabream otolith shape seems to be also sensitive to $\mathrm{pH}$ conditions. Sagitta of juveniles reared at $475 \mu$ atm where indeed significantly shapeless compared to those mineralized at $2000 \mu \mathrm{atm}$. As no asymmetry between left and right otoliths was recorded, no sign of "anomalous" calcification appeared, being in agreement with Maneja et al. (2013) who did not observe a deviation from symmetry in otoliths of Atlantic cod larvae raised at $1800 \mu \mathrm{atm}$ and even at $4200 \mu \mathrm{atm}$. Then, the hereobserved lower otolith roundness with high $p \mathrm{CO}_{2}$ seems to provide evidence that in response to hypercapnia, the otolith not only grows, but also develops more rapidly, acquiring at a higher rate its species-specific ornaments (Campana and Casselman, 1993; Popper et al., 2005). 
298 All these otolith descriptors are important in the otolithic apparatus functioning, as the main 299 organ of the ear in the senses of balance, directed motion detection and hearing (Lychakov and 300 Rebane, 2000; Popper et al., 2005). The otolith features indeed determine the compromise made 301 between these three senses. In bottom-dwelling species such as Sparus aurata, otoliths tend to be 302 bigger relative to the body size than in pelagic species (Popper et al., 2005), improving balance 303 and hearing senses while impairing motion detection. Hearing in seabream has been shown to be 304 a developed sense that is critical for the welfare of juveniles (Filiciotto et al., 2013). Thus, as 305 reported in another Perciform and bottom-dwelling species (Bignami et al., 2013a), ocean 306 acidification, in increasing the size of the otolith relative to the size of the body, may improve 307 the hearing acuity of $S$. aurata. As highlighted by Bignami et al. (2013a) improving auditory 308 capacity could also be advantageous or deleterious depending on the sound spectra newly 309 accessible to the fish. As Filiciotto et al. (2013) reported, wild offshore sound at low pressure 310 levels are more beneficial to $S$. aurata with individuals being less stressed and faster growing 311 than individuals exposed to constant and high sound pressure levels in aquaculture tanks. In 312 increasing hearing acuity, ocean acidification could thus induce a threshold shift of sound 313 pressure tolerance (Smith et al., 2004) or displace the optimum window of frequency, making 314 the baseline sound of the environment more disturbing and stressful (Simpson et al. 2011, Caiger 315 et al., 2012; Filiciotto et al., 2013). As many other ecologically and economically important 316 species fished in the wild and cultured in offshore farms, the consequences of ocean acidification 317 on growth and survival performances related to balance and auditory capacities need to be 318 considered and evaluated.

4.3 Potential repercussions of elevated $\mathrm{pCO}_{2}$ on the otolith as a recorder of the seawater chemistry

322 Considerations have also to be raised in regard to the use by fisheries scientists of the chemical 
323 composition of the otolith as a biological tracking tool (Campana, 2005; Miller et al., 2006).

324 Here, calcium incorporation into the otolith was modulated by seawater $\mathrm{pH}$. This questions the 325 stability of the elemental:Ca ratio under environmental hypercapnia. During the 326 biomineralization of the otolith, chemical elements such as metals and metalloids are supposed 327 to substitute for calcium (Campana, 1999) or, at least for some transition metals, complex with 328 the organic matrix of the otolith via its constitutive metal-binding proteins (Miller et al., 2006). 329 The changes of $\mathrm{pH}$ and seawater chemistry caused by increased $\mathrm{CO}_{2}$ can modify the speciation 330 of metals and therefore their bioavailability to organisms (Millero et al., 2009). The 331 physiological response of fish to hypercapnia might in turn stimulate processes to compensate 332 for acidosis based on the key role of ion transporters such as the $\mathrm{Na}^{+} / \mathrm{H}^{+}$exchangers (Hu et al., 333 2013) that are hypothesized to be a major accumulation pathway for some cationic elements 334 (Webb and Wood, 2000). In this context, ocean acidification may interfere with trace element 335 uptake and body concentrations (Lacoue-Labarthe et al., 2009) and therefore could affect 336 microchemical signature recorded in fish otolith. Two previous studies observed that ocean 337 acidification has no effect on alkaline metals Ba-, $\mathrm{Mg}-$, Sr-Ca ratio in the otolith of larval and 338 juvenile fish (Hurst et al., 2012; Munday et al., 2011a). In contrast, in statoliths of squid larvae, 339 the activity of the transition metal ${ }^{65} \mathrm{Zn}$ has been shown to increase with lowering $\mathrm{pH}$ (Lacoue340 Labarthe et al., 2011). Future research thus seems still needed to investigate the possibility that 341 ocean acidification could impact the incorporation of other trace elements used to track 342 movements of marine organisms (Arkhipkin et al., 2004; Campana et al., 2000), depending on 343 their chemical properties, molecular-binding affinities and incorporation pathway into the 344 otolith.

\section{5. Conclusions}

347 In conclusion, this study demonstrates that, even under projected near-future $p \mathrm{CO}_{2}$ levels, 
348 juvenile seabream exhibited an increase of their otolith calcification and development rates while 349 their body growth rate was not affected. Highlighting an uncoupling of otolith and body growth 350 rates which appeared within $40 \mathrm{~d}$ at a $p \mathrm{CO}_{2}$ of $700 \mu$ atm projected to be reached by the end of 351 the century, this study shows that juvenile seabream could be more resilient to the ongoing ocean 352 acidification in terms of somatic growth than in terms of structural calcification. As the otolith is 353 an essential tool used in reconstructing fish life history in terms of age, somatic growth and 354 attended habitats, this work suggests that information resulting from otolith studies should be 355 interpreted with caution with respect to the potential impacts that ocean acidification projected 356 modifications could have on otolith biomineralization.

\section{Acknowledgments}

359 We thank the staff of the hatchery "Cannes Aquaculture" in Monaco for providing seabream 360 juveniles. The IAEA is grateful for the support provided to its Environment Laboratories by the 361 Government of the Principality of Monaco. This work is a contribution to the "European Project 362 on Ocean Acidification" (EPOCA), which received funding from the European Community 363 (grant agreement 211384).

References

366 Allemand, D., Mayer Gostan, N., De Pontual, H., Boeuf, G., Payan, P., 2007. Fish Otolith 367 Calcification in Relation to Endolymph Chemistry, in: Handbook of Biomineralization Biological Aspects and Structure Formation. Wiley-VCH Verlag GmbH, Weinheim,

Arkhipkin, A.I., Campana, S.E., FitzGerald, J., Thorrold, S.R., 2004. Spatial and temporal variation in elemental signatures of statoliths from the Patagonian longfin squid (Loligo gahi). Can. J. Fish. Aquat. Sci. 61, 1212-1224. 
Baumann, H., Talmage, S.C., Gobler, C.J., 2012. Reduced early life growth and survival in a fish in direct response to increased carbon dioxide. Nat. Clim. Chang. 2, 38-41.

Bignami, S., Enochs, I.C., Manzello, D.P., Sponaugle, S., Cowen, R., 2013a. Ocean acidification alters the otoliths of a pantropical fish species with implications for sensory function. Proc. Natl. Acad. Sci. U.S.A. 110, 7366-7370.

Bignami, S., Sponaugle, S., Cowen, R., 2013b. Response to ocean acidification in larvae of a large tropical marine fish, Rachycentron canadum. Glob. Change Biol. 19, 996-1006.

Blanco, C., Salomo,, O., Raga, J.A., 2001. Diet of the bottlenose dolphin (Tursiops truncatus) in the western Mediterranean Sea. J. Mar. Biol. Ass. U.K. 81, 1053-1058.

Borelli, G., Guibbolini, M.E., Mayer-Gostan, N., Priouzeau, F., De Pontual, H., Allemand, D., Puverel, S., Tambutte, E., Payan, P., 2003. Daily variations of endolymph composition: relationship with the otolith calcification process in trout. J. Exp. Biol. 206, 2685-2692.

Cai, W.J., Hu, X., Huang, W.J., Murrell, M.C., Lehrter, J.C., Lohrenz, S.E., Chou, W.C., Zhai, W., Hollibaugh, J.T., Wang, Y., Pingsan, Z., Guo, X., Gundersen, K., Dai, M., Gong, G.C., 2011. Acidification of subsurface coastal waters enhanced by eutrophication. Nature 4, 766770.

Caiger, P.E., Montgomery, J.C., Radford, C.A., 2012. Chronic low-intensity noise exposure affects the hearing thresholds of juvenile snapper. Mar. Ecol. Prog. Ser. 466, 225-232.

Caldeira, K., Wickett, M.E., 2005. Ocean model predictions of chemistry changes from carbon dioxide emissions to the atmosphere and ocean. J. Geophys. Res. 110.

Campana, S., 1999. Chemistry and composition of fish otoliths: pathways, mechanisms and applications. Mar. Ecol. Prog. Ser. 188, 263-297.

Campana, S., Chouinard, G., Hanson, J., Frechet, A., Brattey, J., 2000. Otolith elemental fingerprints as biological tracers of fish stocks. Fish. Res. 46, 343-357.

Campana, S., Neilson, J., 1985. Microstructure of fish otoliths. Can. J. Fish. Aquat. Sci. 42, 
$1014-1032$.

399 Campana, S.E., 2005. Otolith science entering the 21st century. Mar. Freshwater Res. 56, 485$400 \quad 495$.

401 Campana, S.E., Casselman, J.M., 1993. Stock Discrimination Using Otolith Shape Analysis. 402 Can. J. Fish. Aquat. Sci. 50, 1062-1083.

403 Checkley, D.M., Dickson, A.G., Takahashi, M., Radich, J.A., Eisenkolb, N., Asch, R., 2009. $404 \quad$ Elevated $\mathrm{CO}_{2}$ enhances otolith growth in young fish. Science 324, 1683.

405 Ciais, P., Sabine, C.L., Bala, G., Bopp, L., Brovkin, V., Canadell, J., Chhabra, A., DeFries, R., 406 Galloway, J., Heimann, M., Jones, C., Le Quéré, C., Myneni, R., Piao, S., Thornton, P., 407 2013. Carbon and other biogeochemical cycles, in: Climate Change 2013 : the Physical 408 Science Basis. Cambridge University Press, Cambridge, United Kindgom and New York, $409 \quad$ NY, USA, pp. 465.

410 Crawley, M.J., 2005. Statistics: an introduction using R. Wiley, West Sussex, England 328 pp.

411 Dickson, A.G., Sabine, C.L., Christian, J.R., 2007. Guide to best practices for ocean $\mathrm{CO}_{2}$ 412 measurements. PICES Special Publication 3.

413 Dorey, N., Melzner, F., Martin, S., Oberhänsli, F., Teyssié, J.-L., Bustamante, P., Gattuso, J.-P., 414 Lacoue-Labarthe, T., 2012. Ocean acidification and temperature rise: effects on calcification 415 during early development of the cuttlefish Sepia officinalis. Mar. Biol. 160, 2007-2022.

416 Fabry, V.J., Seibel, B.A., Feely, R.A., Orr, J.C., 2008. Impacts of ocean acidification on marine 417 fauna and ecosystem processes. ICES J. Mar. Sci. 65, 414-432.

418 FAO, 2014. Cultured Aquatic Species Information Programme Sparus aurata.

419 Filiciotto, F., Giacalone, V.M., Fazio, F., Buffa, G., Piccione, G., Maccarrone, V., Di Stefano, 420 V., Mazzola, S., Buscaino, G., 2013. Effect of acoustic environment on gilthead seabream 421 (Sparus aurata): Sea and onshore aquaculture background noise. Aquaculture 414-415, 36422 45. 
Gattuso, J.P., Frankignoulle, M., Wollast, R., 1998. CARBON AND CARBONATE METABOLISM IN COASTAL AQUATIC ECOSYSTEMS. Annu. Rev. Ecol. Syst. 29, $405-434$.

GFCM, 2013. Trend and issues of aquaculture in the Mediterranean and Black Sea, in:. Presented at the Eighth Session of the Committee on Aquaculture CAQ, Paris, France, p. 5.

Guinotte, J.M., Fabry, V.J., 2008. Ocean acidification and its potential effects on marine ecosystems. Ann. N. Y. Acad. Sci. 1134, 320-342.

Gutowska, M.A., Melzner, F., Pörtner, H.O., Meier, S., 2010. Cuttlebone calcification increases during exposure to elevated seawater $p \mathrm{CO}_{2}$ in the cephalopod Sepia officinalis. Mar. Biol. $157,1653-1663$.

Havenhand, J., Dupont, S., Quinn, G.P., 2010. Designing ocean acification experiments to maximise inference. In: Riebesell, U., Fabry, V.J., Hanson, L., Gattuso, J.P. (Eds.), Guide for best practices in ocean acidification research and data reporting. Publications Office of the European Unit, Luxembourg, pp. 67-80.

Hilmi, N., Allemand, D., Dupont, S., Safa, A., Haraldsson, G., Nunes, P.A.L.D., Moore, C., Hattam, C., Reynaud, S., Hall-Spencer, J.M., Fine, M., Turley, C., Jeffree, R., Orr, J., Munday, P., Cooley, S.R., 2013. Towards improved socio-economic assessments of ocean acidification's impacts. Mar. Biol. 160, 1773 Allem

Hu, M.Y., Lee, J.-R., Lin, L.-Y., Shih, T.-H., Stumpp, M., Lee, M.-F., Hwang, P.-P., Tseng, Y.C., 2013. Development in a naturally acidified environment: $\mathrm{Na}^{+} / \mathrm{H}^{+}$-exchanger 3-based proton secretion leads to $\mathrm{CO}_{2}$ tolerance in cephalopod embryos. Front. Zool. 10, 51.

Hurlbert, S.H., 1984. Pseudoreplication and the design of ecological field experiments. Ecol. Monogr. 54, 187-211.

Hurst, T.P., Fernandez, E.R., Mathis, J.T., Miller, J.A., Stinson, C.M., Ahgeak, E.F., 2012. Resiliency of juvenile walleye pollock to projected levels of ocean acidification. Aquat. 
Biol. 17, 247-259.

IPCC, 2013. Climate Change 2013 : The Physical Science Basis. Cambridge University Press, Cambridge, United Kindgom and New York, NY, USA.

Ishimatsu, A., Hayashi, M., Kikkawa, T., 2008. Fishes in high- $\mathrm{CO}_{2}$, acidified oceans. Mar. Ecol. Prog. Ser. 373, 295-302.

Kalogeropoulos, N., Alexis, M.N., Henderson, R.J., 1992. Effects of dietary soybean and codliver oil levels on growth and body composition of gilthead bream (Sparus aurata). Aquaculture 104, 293-308.

Kim, S.S., Rahimnejad, S., Song, J.W. and Lee, K.J. 2012. Comparison of growth performance and whole-body amino acid composition in red seabream (Pagrus major) fed free or dipeptide form of phenylalanine. Asian-Australian J. Anim. Sci., 25:1138-1144.

Kopecka-Pilarczyk, J., Correia, A.D., 2009. Biochemical response in gilthead seabream (Sparus aurata) to in vivo exposure to pyrene and fluorine. J. Exp. Mar. Biol. Ecol. 37, 49-57.

Lacoue-Labarthe, T., Martin, S., Oberhansli, F., Teyssie, J.-L., Markich, S., Ross, J., Bustamante, P., 2009. Effects of increased $p \mathrm{CO}_{2}$ and temperature on trace element $(\mathrm{Ag}, \mathrm{Cd}$ and $\mathrm{Zn}$ ) bioaccumulation in the eggs of the common cuttlefish, Sepia officinalis. Biogeosciences 6, 2561-2573.

Lacoue-Labarthe, T., Réveillac, E., Oberhänsli, F., Teyssié, J.L., Jeffree, R., Gattuso, J.P., 2011. Effects of ocean acidification on trace element accumulation in the early-life stages of squid Loligo vulgaris. Aquat. Toxicol. 105, 166-176.

Le Quéré, C., Andres, R.J., Boden, T., Conway, T., Houghton, R.A., House, J.I., Marland, G., Peters, G.P., van der Werf, G.R., Ahlström, A., Andrew, R.M., Bopp, L., Canadell, J.G., Ciais, P., Doney, S.C., Enright, C., Friedlingstein, P., Huntingford, C., Jain, A.K., Jourdain, C., Kato, E., Keeling, R.F., Klein Goldewijk, K., Levis, S., Levy, P., Lomas, M., Poulter, B., Raupach, M.R., Schwinger, J., Sitch, S., Stocker, B.D., Viovy, N., Zaehle, S., Zeng, N., 
2013. The global carbon budget 1959-2011. Earth Syst. Sci. Data 5, 165-185.

Lychakov, D.V., Rebane, Y.T., 2000. Otolith regularities. Hear. Res. 143, 83-102.

Maneja, R., Frommel, A., Geffen, A.J., Folkvord, A., Piatkowski, U., Chang, M.Y., Clemmesen, C., 2013. Effects of ocean acidification on the calcification of otoliths of larval Atlantic cod Gadus morhua. Mar. Ecol. Prog. Ser. 477, 251-258.

Markaida, U., Sosa-Nishizaki, O., 2003. Food and feeding habits of jumbo squid Dosidicus gigas (Cephalopoda: Ommastrephidae) from the Gulf of California, Mexico. J. Mar. Biol. Ass. U.K. 83, 507-522.

Martin, S., Richier, S., Pedrotti, M.-L., Dupont, S., Castejon, C., Gerakis, Y., Kerros, M.-E., Oberhänsli, F., Teyssié, J.-L., Jeffree, R., Gattuso, J.-P., 2011. Early development and molecular plasticity in the Mediterranean sea urchin Paracentrotus lividus exposed to $\mathrm{CO}_{2^{-}}$ driven acidification. J. Exp. Biol. 214, 1357-1368.

Melzner, F., Göbel, S., Langenbuch, M., Gutowska, M.A., Pörtner, H.O., Lucassen, M., 2009a. Swimming performance in Atlantic Cod (Gadus morhua) following long-term (4-12 months) acclimation to elevated seawater $p \mathrm{CO}_{2}$. Aquat. Toxicol. 92, 30-37.

Melzner, F., Gutowska, M.A., Langenbuch, M., Dupont, S., Lucassen, M., Thorndyke, M.C., Bleich, M., Pörtner, H.O., 2009b. Physiological basis for high $\mathrm{CO}_{2}$ tolerance in marine ectothermic animals: pre-adaptation through lifestyle and ontogeny? Biogeosciences 6, 2313-2331.

Michaelidis, B., Spring, A., Pörtner, H.O., 2007. Effects of long-term acclimation to environmental hypercapnia on extracellular acid-base status and metabolic capacity in Mediterranean fish Sparus aurata. Mar. Biol. 150, 1417-1429.

Mihelakakis, A., Tsolkas, C., Yoshimatsu, T., 2002. Optimization of feeding rate for hatcheryproduced juvenile gilthead sea bream Sparus aurata. J. World. Aquac. Soc. 33, 169-175.

Miller, M.B., Clough, A.M., Batson, J.N., Vachet, R.W., 2006. Transition metal binding to cod 
otolith proteins. J. Exp. Mar. Biol. Ecol. 329, 135-143.

499 Millero, F., Woosley, R., DiTrolio, B., Waters, J., 2009. Effect of Ocean Acidification on the $500 \quad$ Speciation of Metals in Seawater. Oceanography 22, 72-85.

501 Mosegaard, H., Svedäng, H., Taberman, K., 1988. Uncoupling of Somatic and Otolith Growth Rates in Arctic Char (Salvelinus alpinus) as an Effect of Differences in Temperature Response. Can. J. Fish. Aquat. Sci. 45, 1514-1524.

Munday, P., Donelson, J.M., Dixson, D., Endo, G.G.K., 2009. Effects of ocean acidification on the early life history of a tropical marine fish. Proc. R. Soc. B 276, 3275-3283.

Munday, P.L., Gagliano, M., Donelson, J.M., Dixson, D.L., Thorrold, S.R., 2011a. Ocean acidification does not affect the early life history development of a tropical marine fish. Mar. Ecol. Prog. Ser. 423, 211-221.

Munday, P.L., Hernaman, V., Dixson, D.L., Thorrold, S.R., 2011b. Effect of ocean acidification on otolith development in larvae of a tropical marine fish. Biogeosciences 8, 1631-1641.

Proye, A., Gattuso, J.P., 2003. Seacarb, an R package to calculate parameters of the seawater carbonate system.

R Core Team, 2013. R: A language and environment for statistical computing. R Foundation for 


\section{Statistical Computing, Vienna, Austria. ISBN 3-900051-07-0.}

Riebesell, U., Zondervan, I., Rost, B., Tortell, P.D., Zeebe, R.E., Morel, F.M., 2000. Reduced calcification of marine plankton in response to increased atmospheric $\mathrm{CO}_{2}$. Nature 407, 364367.

Ries, J.B., Cohen, A.L., McCorkle, D.C., 2009. Marine calcifiers exhibit mixed responses to $\mathrm{CO}_{2}$-induced ocean acidification. Geology $37,1131-1134$.

Ross, R.M., Johnson, J.H., Adams, C.M., 2005. Use of fish-otolith-length regressions to infer size of double-crested cormorant prey fish from recovered otoliths in Lake Ontario. Northeastern Naturalist 12, 133-140.

Secor, D.H., Dean, J.M., 1989. Somatic growth effects on the otolith-fish size relationship in young pond-reared striped bass, Morone saxatilis. Can. J. Fish. Aquat. Sci. 46, 113-121.

Simpson, S., Munday, P., Wittenrich, M., Manassa, R., Dixson, D., Gagliano, M., Yan, H., 2011. Ocean acidification erodes crucial auditory behaviour in a marine fish. Biol. Lett. 7, 917920.

Smith, M.E., Kane, A.S., Popper, A.N., 2004. Acoustical stress and hearing sensitivity in fishes: does the linear threshold shift hypothesis hold water? J. Exp. Biol. 207, 3591-3602.

Takasuka, A., Oozeki, Y., Aoki, I., Kimura, R., Kubota, H., Sugisaki, H., Akamine, T., 2008. Growth effect on the otolith and somatic size relationship in Japanese anchovy and sardine larvae. Fish. Sci. 74, 308-313.

Webb, N.A., Wood, C.M., 2000. Bioaccumulation and distribution of silver in four marine teleosts and two marine elasmobranchs: influence of exposure duration, concentration, and salinity. Aquat. Toxicol. 49, 111 mari

Wilson, J.A., Vigliola, L., Meekan, M.G., 2009. The back-calculation of size and growth from otoliths: validation and comparison of models at an individual level. J. Exp. Mar. Biol. Ecol. $368,9-21$. 
548 Zeebe, R.E., Ridgwell, A., 2011. Past changes in ocean carbonate chemistry. In: Gattuso, J.P., 549 Hansson, L. (Eds.), Ocean Acidification. Oxford, New-York, US, pp. 21-40. 
TABLES

551

552 Table 1. Sparus aurata. Carbonate chemistry and $\mathrm{pH}$ (mean $\pm \mathrm{sd}$ ) in the four $\mathrm{pH}$ levels applied 553 to reared juvenile of seabream for $40 \mathrm{~d}$ (1 tank per treatment). Partial pressure of $\mathrm{CO}_{2}\left(p \mathrm{CO}_{2} ; \mu \mathrm{atm}\right)$, 554 dissolved inorganic carbon (DIC; $\mu$ mol. $\left.\mathrm{kg}^{-1}\right), \mathrm{CO}_{3}{ }^{2-}$ concentration $\left(\mu\right.$ mol. $\mathrm{kg}^{-1}$ ) and saturation state of seawater with 555 respect to aragonite $\left(\Omega_{\mathrm{arg}}\right)$ are calculated from $\mathrm{pH}_{\mathrm{T}}$, temperature $\left(21.0^{\circ} \mathrm{C}\right)$, salinity $(38)$ and the total alkalinity 556 varying with time between two water renewals according the following equation: TA $\left(\mu\right.$ mol. $\left.\mathrm{kg}^{-1}\right)=2599+196 \mathrm{x}$ 557 Time (day). Data are means \pm s.d. of measurements taken every 15 min from Day 0 to Day 40; N = 24,724.

558

\begin{tabular}{lccccc}
\hline Treatment & $\mathrm{pH}_{\mathrm{T}}$ & $p \mathrm{CO}_{2}$ & $\mathrm{DIC}$ & $\mathrm{CO}_{3}{ }^{2-}$ & $\Omega_{\text {arg }}$ \\
& & & & \\
pH 8.1 & $8.04 \pm 0.05$ & $477 \pm 78$ & $2412 \pm 341$ & $238 \pm 22$ & $3.65 \pm 0.34$ \\
pH 7.9 & $7.89 \pm 0.05$ & $726 \pm 101$ & $2506 \pm 247$ & $178 \pm 15$ & $2.73 \pm 0.23$ \\
pH 7.7 & $7.69 \pm 0.03$ & $1198 \pm 105$ & $2603 \pm 153$ & $121 \pm 8$ & $1.85 \pm 0.13$ \\
pH 7.5 & $7.50 \pm 0.06$ & $1978 \pm 202$ & $2685 \pm 244$ & $80 \pm 13$ & $1.22 \pm 0.19$ \\
\hline
\end{tabular}


560 Table 2. Sparus aurata. Parameters of the multiple linear regressions between fish total length

561 (FTL, mm) and Time (days), fish total weight (FTW, g) and Time (days) otolith surface area

$562\left(\mathrm{OSA}, \mathrm{mm}^{2}\right)$ and FTL, otolith weight (OW) and OSA, otolith Feret maximum diameter (OF,

$563 \mathrm{~mm}$ ) and FTL, and $\mathrm{pH}$ considered as a continuous co-variable, measured over the 40 days period

564 of experiment in 4 tanks maintained at $\mathrm{pH} 7.5,7.7,7.9$ and 8.1. Significance of $p$-values ${ }^{\mathrm{NS}}>$

$5650.05 ;^{*}<0.05 ;^{* *}<0.01 ;^{* * *}<0.001$.

\begin{tabular}{|c|c|c|c|c|}
\hline Model & Parameter & $\begin{array}{l}\text { Variable } \\
\text { p-value }\end{array}$ & $\begin{array}{l}\text { Model } \\
\text { F-value }\end{array}$ & $\begin{array}{l}\text { Model } \\
\text { p-value }\end{array}$ \\
\hline \multirow[t]{2}{*}{ FTL $v s$. Time } & Time & $<0.001 * * *$ & 117.1 & $<0.001 * * *$ \\
\hline & $\mathrm{pH}$ & $0.654^{\mathrm{NS}}$ & & \\
\hline \multirow[t]{2}{*}{ FTW vs. Time } & Time & $<0.001 * * *$ & 85.8 & $<0.001 * * *$ \\
\hline & $\mathrm{pH}$ & 0.372 & & \\
\hline \multirow[t]{3}{*}{ OSA vs. FTL } & FTL & $0.002 * *$ & 246.9 & $<0.001 * * *$ \\
\hline & $\mathrm{pH}$ & $0.046^{*}$ & & \\
\hline & FTL x pH & $0.021^{*}$ & & \\
\hline \multirow[t]{2}{*}{ OW vs. OSA } & OSA & $<0.001 * * *$ & 737.3 & $<0.001 * * *$ \\
\hline & $\mathrm{pH}$ & $0.772^{\mathrm{NS}}$ & & \\
\hline \multirow[t]{2}{*}{ OF vs. FTL } & FTL & $0.002 * *$ & 280.2 & $<0.001 * * *$ \\
\hline & $\mathrm{pH}$ & $0.636^{\mathrm{NS}}$ & & \\
\hline
\end{tabular}

Model degree of freedom: 3 and 186 
567 Table 3. Sparus aurata. Daily rate of calcium incorporation (mmol.gotolith dry weight ${ }^{-1} \cdot \mathrm{d}^{-1} ;$ mean \pm

$568 \mathrm{sd}$ ) in otolith and parameters of the multiple linear regressions with $\mathrm{pH}$ as continuous factor.

\begin{tabular}{|c|c|c|c|c|c|c|}
\hline \multirow[t]{2}{*}{$\mathrm{pH}_{\mathrm{T}}$} & \multirow[t]{2}{*}{$\mathrm{N}$} & \multirow[t]{2}{*}{ Ca incorp. rate } & \multirow[t]{2}{*}{$\mathrm{R}^{2}$} & \multicolumn{3}{|c|}{ Multiple linear regression } \\
\hline & & & & Parameters & Par. p-value & Model \\
\hline pH 8.1 & 49 & $0.052 \pm 0.001$ & 0.962 & Time & $<0.001$ & F test: 1753 \\
\hline pH 7.9 & 48 & $0.060 \pm 0.002$ & 0.969 & $\mathrm{pH}$ & 0.369 & $\mathrm{P}<0.001$ \\
\hline pH 7.7 & 49 & $0.062 \pm 0.002$ & 0.974 & Time $\mathrm{x} \mathrm{pH}$ & $<0.001$ & \\
\hline pH 7.5 & 50 & $0.062 \pm 0.001$ & 0.965 & & & \\
\hline
\end{tabular}

$569 \quad \mathrm{R}^{2}$ : determination coefficient; Model degree of freedom : 3 and $187 \mathrm{df}$. 

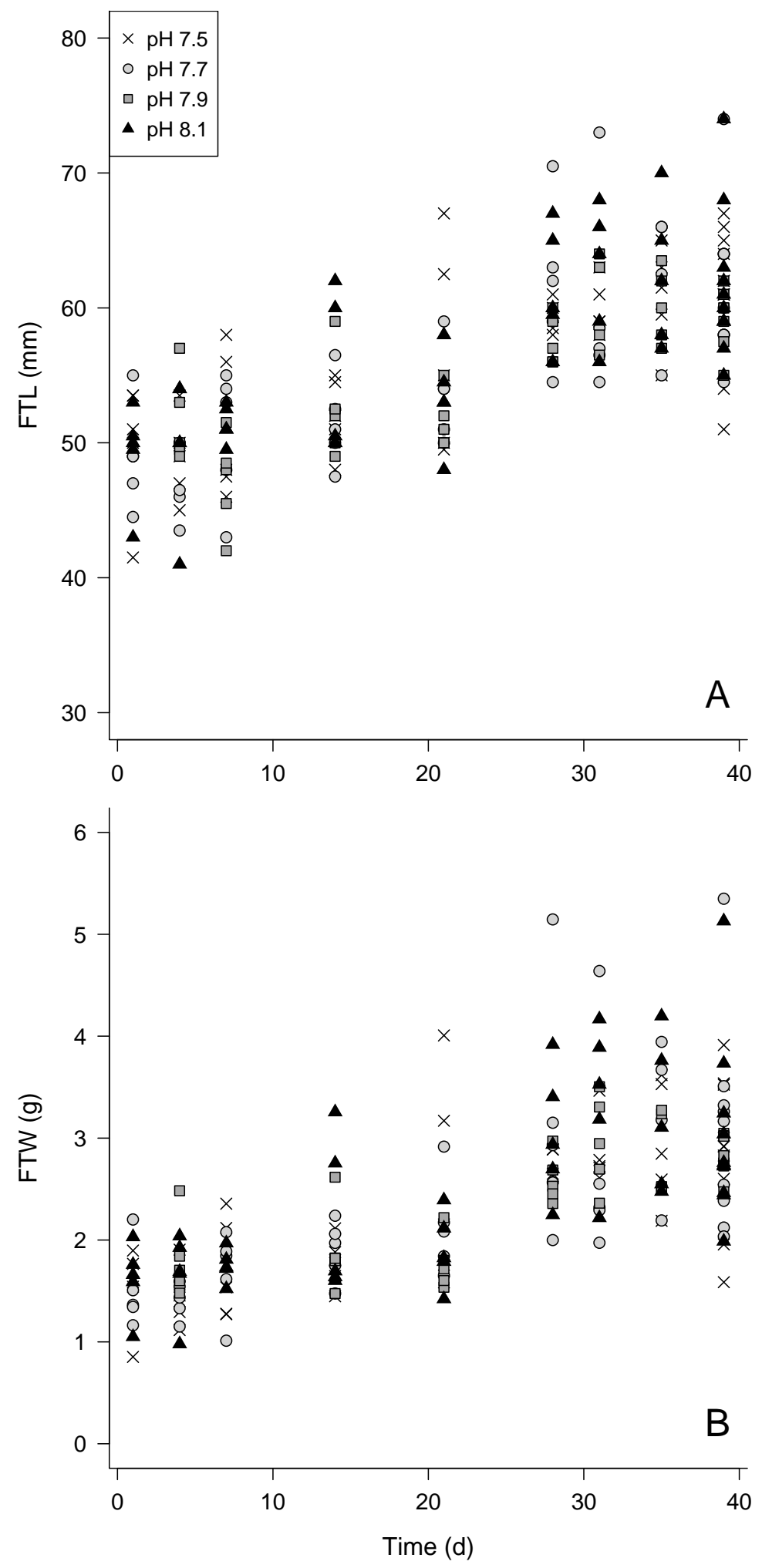

571 Figure 1. Sparus aurata. (A) Fish total length $(\mathrm{mm})$ versus time (days of experiment) in the 573 different $\mathrm{pH}$ conditions. (B) Fish total weight $(\mathrm{g})$ versus time (days of experiment) in the 574 different $\mathrm{pH}$ conditions. 


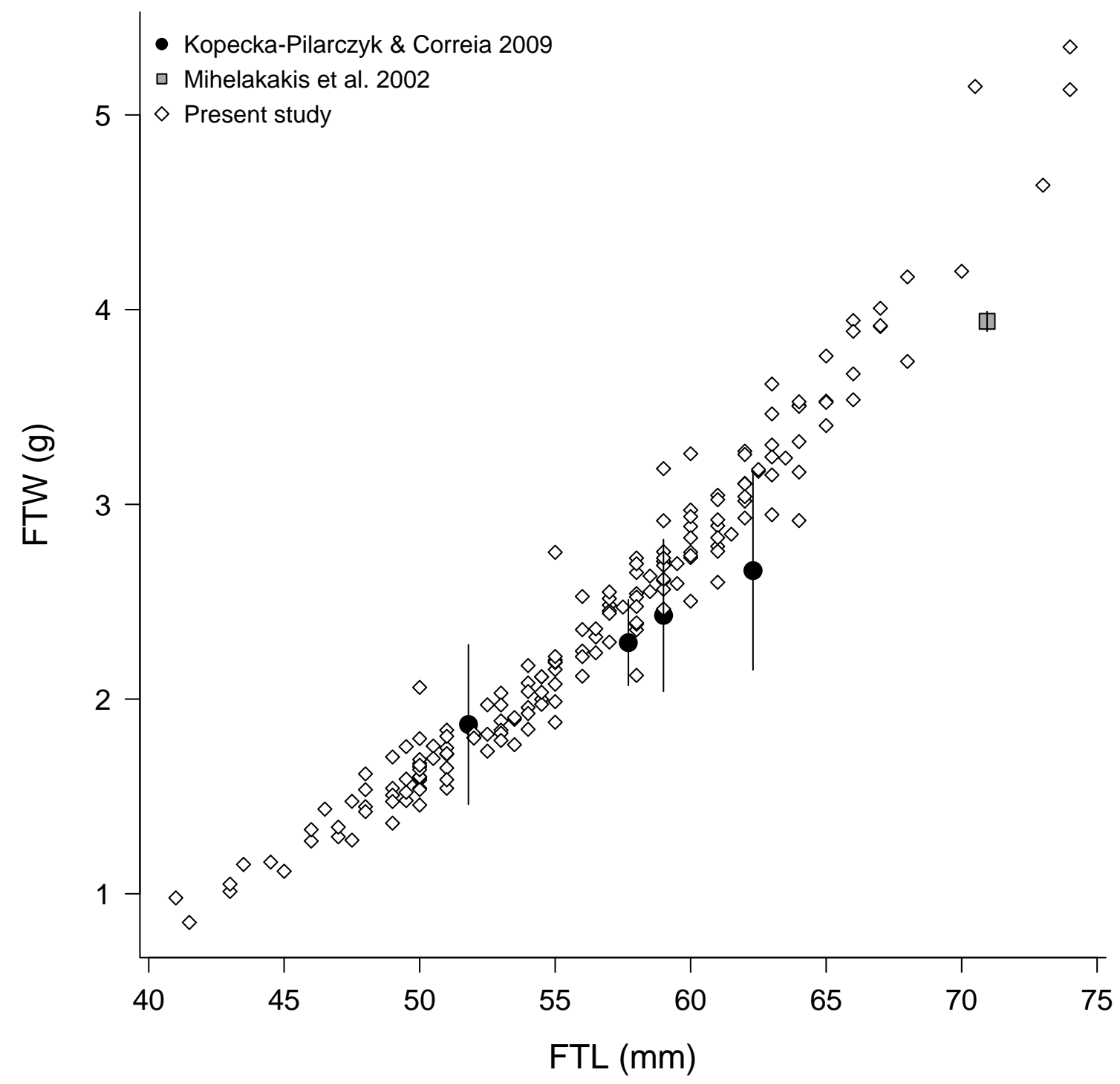

Figure 2. Sparus aurata. Fish total weight $(\mathrm{g})$ versus fish total length $(\mathrm{mm})$ recorded individually in this study (all $4 \mathrm{pH}$ conditions merged) and means ( \pm sd for weight) reported by 578 Mihelakakis et al. (2002) and Kopecka-Pilarczyk and Correia (2009). 

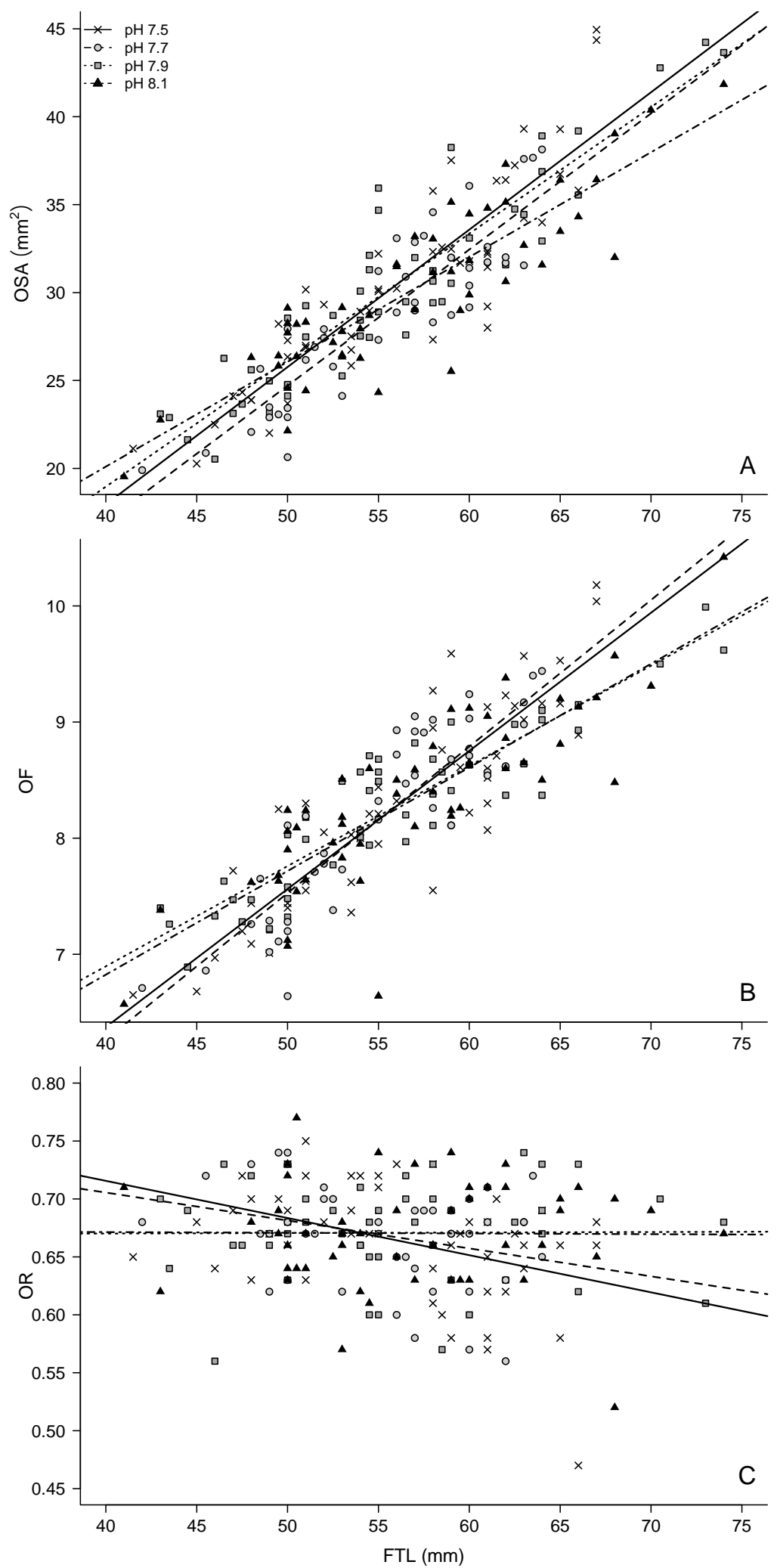

Figure 3. Sparus aurata. (A) Allometric relationship between the otolith surface area (OSA, $\mathrm{mm}^{2}$ ) and the fish total length (FTL, mm), (B) Otolith Feret maximum diameter (OF) and (C) otolith roundness $(\mathrm{OR})$ measured in juvenile seabreams raised during $40 \mathrm{~d}$ at four different $\mathrm{pH}_{\mathrm{T}}$ treatments 7.5, 7.7, 7.9, and 8.1 ( 1 tank per treatment, see Table 2 for statistical significance). An otolith roundness value of 1 means a circular shape. For OR, only data recorded at $\mathrm{pH} 7.5$ were significantly linearly distributed (full black line, $p=0.0046$ ). 

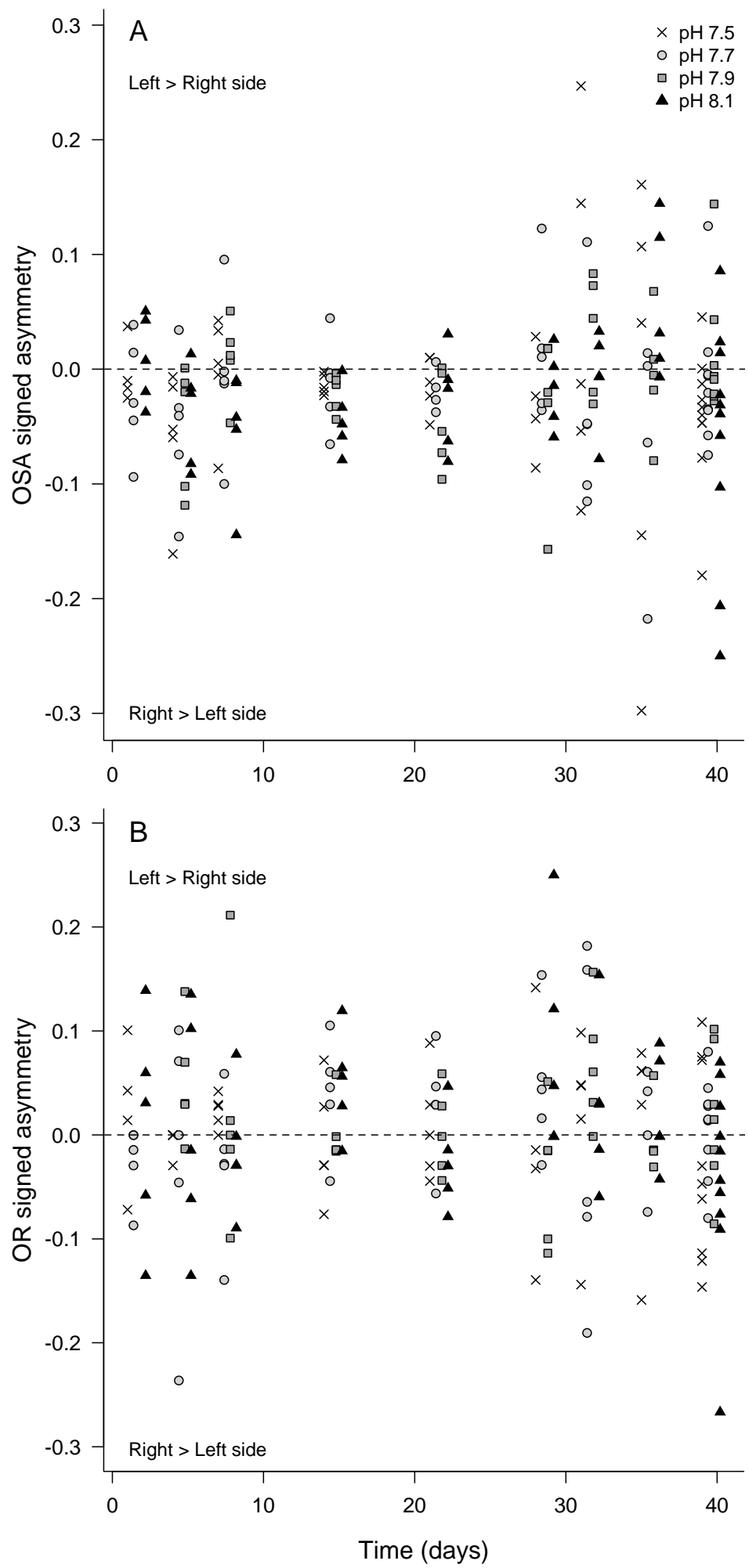

587 Figure 4. Sparus aurata. Asymmetry ([left - right $] /$ mean $_{\text {left, right }}$ ) in (A) otolith surface area (OSA) 588 and (B) otolith roundness (OR) between left and right sagitta of juveniles reared at $4 \mathrm{pH}$ 589 treatments 7.5, 7.7, 7.9, and 8.1 (1 tank per treatment) during $40 \mathrm{~d}$. Dashed-line represents 590 symmetry; offset in the $x$-axis was used to display the data per $\mathrm{pH}$ treatment. 


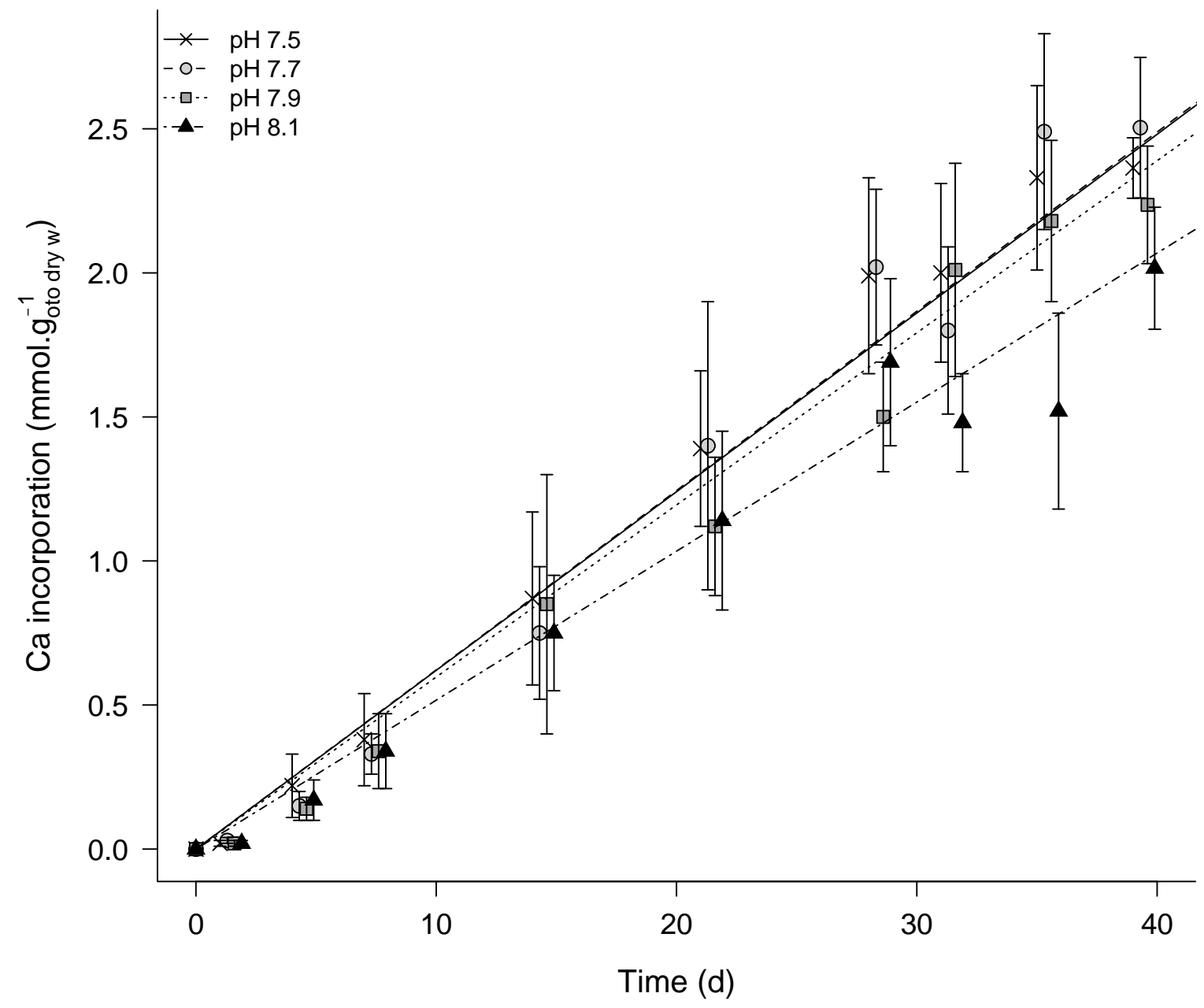

Figure 5. Sparus aurata. Incorporation of calcium (mmol.g $\mathrm{g}_{\text {otolith dry weight }}{ }^{-1} \pm \mathrm{sd}$ ) in sagittal otolith 594 of juvenile seabreams reared at $4 \mathrm{pH}$ treatments $7.5,7.7,7.9$, and 8.1 (1 tank per treatment) 595 during $40 \mathrm{~d}$. Offset in the $x$-axis was used to display the data per $\mathrm{pH}$ treatment. See Table 3 for 596 data and statistical comparisons. Rates of $\mathrm{Ca}$ incorporation calculated on pseudoreplicates at $\mathrm{pH}_{\mathrm{T}}$ 5978.1 are 18,27 and $25 \%$ lower than rates at $\mathrm{pH}_{\mathrm{T}} 7.9,7.7$ and 7.5, respectively. 